* Doutora em Direito do Estado pela Universidade de São Paulo - USP. Mestre em Direito pela Universidade Federal de Santa Catarina - UFSC. Coordenadora executiva da pósgraduação em Direito do Trabalho CNEC-Gravataí. Professora CNEC-Gravataí E-mail: ninadisconzi@uol. com.br

** Mestre em direito pela PUCRS. Professor na graduação e pós-graduação da CNEC-Gravataí. Advogado. E-mail: julianog@professor. facensa.edu.br

\section{A responsabilidade pré-contratual no Direito do Trabalho brasileiro}

\author{
THE PRE-CONTRACTUAL LIABILITY IN \\ BraZiLIAN LABOR LAW
}

* Nina Trícia Disconzi Rodrigues
** Juliano Gianechini Fernandes

Resumo: A conclusão de um contrato é precedida de uma fase de negociações, contatos entre as partes. Nas relações empregatícias o mesmo ocorre, porém a expectativa do trabalhador é sempre maior. Em virtude da não concretização do negócio contratual, há possibilidade de indenização por danos materiais e/ou extrapatrimoniais, sendo ônus do atingido a demonstração do dano ocorrido. As normas do direito privado devem adequar-se aos princípios jurídicos norteadores da ordem macrossocial, como o respeito à boa-fé.

Palavras-chave: Responsabilidade civil pré-contratual; Contrato de emprego; Boa-fé contratual.

Abstract: The conclusion of a contract is preceded by a phase of negotiations, and contacts between the parties. In employment relations, the same occurs, however the expectation of the worker is always greater. Due to the non-consolidation of the transaction contract, a possibility of compensation for material damages exists, and or off- balance sheet, the lien being reaching demonstration of damage done. The rules of Private Law must adapt itself to legal principles, guiding macro social order, such as the respect for good faith.

Keywords: Civil responsibility pre-contractual; Employment contract; Good faith in contract law. 


\section{INTRODUÇÃO}

Essa pesquisa visa investigar o alcance da responsabilidade pré-contratual no ambiente laboral, na medida em que são cada vez mais frequentes as tratativas preliminares, nas relações jurídicas trabalhistas.

Justifica-se a importância do tema escolhido pela constatação de que, no meio industrializado e tecnológico contemporâneo, são cada vez mais frequentes os negócios em que as respectivas preliminares se alongam e adquirem importância, criando expectativa aos candidatos das futuras vagas de emprego, que a cada fase do processo seletivo, acreditam na possibilidade de serem os escolhidos.

Nessa ótica, cabe, à título introdutório, uma reflexão a respeito do que vem a ser um contrato e, principalmente; como se forma, a fim de se melhor entender o alcance e extensão da responsabilidade pré-contratual nos dias hodiernos.

Sabe-se, em termos singelos, que um contrato é um acordo de vontades, e que, por vezes, em consequência da "sociedade de massas", essa vontade é apenas uma vontade de contratar; uma vontade, por assim dizer, mínima, a qual consubstancia o chamado contrato de adesão. Nessa medida, tem-se como escopo a verificação da incidência da responsabilidade pré-contratual nesse campo do direito.

Por outro prisma, serão analisados não só os fundamentos legais adotados pela legislação trabalhista, mas também os preceitos do Código Civil Brasileiro de 2002 aplicáveis 'a seara laboral.

Irá se perquirir se os conceitos de boa-fé objetiva e função social do contrato devem influenciar a interpretação, também nas relações e trabalho e, em qual medida, isso pode ocorrer. Verificar-se-á também a recusa em contratar e a quebra das negociações preliminares, de modo a demonstrar a incidência do instituto em análise.

Hoje, mais do que nunca, pode-se falar das obrigações assumidas como partes de um processo, de deveres anexos que se sobrepõe e assumem a mesma importância dos deveres principais, em uma relação jurídica, em um processo obrigacional.

Por outro lado, nota-se que o desenvolvimento da publicidade, do marketing, e dos meios de comunicação modernos, como a internet, ao mesmo tempo em que ampliaram as relações de consumo, tornaram necessárias uma série de reflexões sobre a necessidade e as consequências daí advindas, das 
negociações anteriores ao contrato definitivo, especialmente sob a ótica laboral, onde carecem pesquisas nesse sentido.

\section{A FORMAÇÃO DO CONTRATO DE EMPREGO COMO NEGÓCIO JURÍDICO}

O contrato de trabalho possui antecedente no Direito Romano, mais precisamente na idade antiga na locatio conductio operarum, modalidade contratual onde havia a prestação de serviço por uma pessoa com remuneração fixada em vista do tempo gasto, não o resultado do trabalho, arcando o credor do trabalho com os riscos.

Se verificados os conceitos de empregado e empregador nos artigos $3^{\circ} \mathrm{e}$ $4^{\circ}$ da CLT, vê-se que estão devidamente enquadrados na situação acima, porém, é claro, com acréscimos devido à evolução da sociedade. Há de se ressaltar ainda no mesmo sentido, o artigo $4^{\circ}$ na norma obreira, consolidando a teoria do tempo à disposição para estabelecer o período mínimo em que o trabalhador deve estar no local de trabalho para receber sua remuneração, exercendo atividades, ou simplesmente ao dispor da empresa.

Utilizando a norma trabalhista para conceituar o contrato de trabalho, pode-se afirmar, de acordo com os artigos 442 e 443 da CLT, que se trata do acordo tácito ou expresso correspondente à relação de emprego, por prazo determinado ou indeterminado.

O contrato de emprego é, em primeiro lugar, gerado de acordo com a necessidade dos empregadores, moldando-se inicialmente de acordo com a situação fática estabelecida pelo empresário. Em suas características, diz-se em primeiro lugar que é intuito persone, portanto personalíssimo, tratando-se de obrigação infungível.

Em segundo lugar, o contrato de trabalho é negócio comutativo, sinalagmático e oneroso para ambas as partes, pois contém obrigações certas e determinadas para empregado e empregador, nitidamente com valor econômico. Obrigações que se renovam periodicamente haja vista tratar-se de relação de trato sucessivo, sendo esta a terceira característica a se chamar atenção.

Há de se dizer também que o contrato de emprego é consensual, visto que nenhuma das partes, ao menos em regra, tem obrigação de celebrar o negócio. Ao final das características, importante mencionar que o contrato de emprego se desenvolve tendo por base a legislação como forma de proteção ao elo mais fraco, ou seja, o empregado. 
Como todo negócio jurídico, para a formação do contrato de emprego é necessário ver se a relação atende aos ditames do artigo 104 do Código Civil, ou seja, capacidade, objeto lícito, possível ou determinável, e forma prescrita ou não defesa em lei.

Ensina Enzo Roppo (1988, p. 8-9) que a substância real de qualquer contrato pode ser resumida na ideia de operação econômica. Há, por assim dizer, uma "captura" das operações econômicas pelo direito.

Por outro lado, a proposta e a aceitação de um contrato (e das declarações de vontade, de uma forma geral) podem, em princípio, ser expressas de qualquer modo: com palavras escritas, com palavras faladas, até com um comportamento concludente que prescinda de palavras: basta apenas a presença da vontade de concluir o contrato e o conteúdo que a este se tenciona dar. É o chamado princípio da liberdade de forma.

A conclusão de um contrato é geralmente precedida e preparada por uma fase de "negociações", a fase, pode-se dizer, do "contato". Nessa fase as partes discutem termos e condições do negócio, a fim de procurar um ponto de equilíbrio entre as respectivas posições de interesses e depois para atingir a formulação de um regulamento contratual que satisfaça as exigências de ambas e por ambas possa ser aceito.

Se consegue chegar a um tal ponto de equilíbrio e conjugação de interesses contrapostos, as negociações conduzem à conclusão do contrato; outras vezes, no entanto, as negociações falham e o contrato não se conclui.

Ademais, no que diz respeito às relações de emprego, muitas vezes, no universo contratual, a conclusão dos contratos não representa o êxito das negociações, de uma discussão livre e paritária entre os contraentes, sobre cada uma das cláusulas, mas é, antes de tudo, o fruto de uma imposição unilateral de um contrato pré-fixado antecipadamente por uma das partes, geralmente sob a forma de modelo impresso - à outra parte, que se limita a aceitá-lo. Isso também ocorre geralmente nas relações de consumo.

Seja nas hipóteses em que se chega à formação do contrato, seja nas hipóteses em que as negociações se interrompem sem uma conclusão útil, pode acontecer que, no decurso das mesmas, uma das partes se comporte de modo desleal e, atendendo apenas a seu próprio interesse e ao seu próprio proveito, tome iniciativas que prejudiquem injustamente a outra parte.

Como exemplo, se pode citar aquela empresa que esgotou suas fases de seleção dos candidatos confirmando que a vaga iria ser preenchida por um dos 
concorrentes. Após novas diretrizes da empresa em meio ao processo seletivo, foi decidido que não mais era necessário contratar para a função que abrira vaga. O candidato, mesmo após ser aprovado, não será contratado.

Ou o comportamento de A que, maliciosamente, prolonga as negociações e, depois de ter incutido na outra parte, B, confiança, em torno da segura conclusão da contratação, interrompe-as bruscamente para fazer o negócio com $\mathrm{C}$, com o qual já estava negociando, às ocultas de B. Aqui vai se consubstanciar a recusa de contratar.

\section{OS FUNDAMENTOS E A EVOLUÇÃO NA DOUTRINA DA NOÇÃO DE RESPONSABILIDADE PRÉ- CONTRATUAL}

Récio E. Cappelari (1995, p. 19) informa que no final do século XIX, Jhering foi o primeiro escritor a realizar um estudo sistemático da responsabilidade pré-contratual. Formulou, então, a doutrina da culpa in contrahendo ou responsabilidade pré-contratual.

Maria C. Cachapuz (1999, p. 67) explica que, pelos estudos do jurista alemão ainda não era, naquela época, possível se compreender a necessidade de ressarcimento imposta por prejuízos causados na fase preparatória de um contrato ao quadro geral da responsabilidade civil, polarizado entre responsabilidade contratual e extracontratual.

Assim, se por um lado os prejuízos verificados decorrem de um interesse específico na formação de um determinado negócio jurídico, por outro, não se poderia ainda falar em concretização desse negócio jurídico, uma vez que ocorrida, justamente, uma ruptura das negociações pretendidas. A dificuldade reside no fato de, na fase pré-contratual, não ser reconhecida ainda a existência de um vínculo jurídico entre as partes, mas decorrerem os danos de uma tentativa de formação desse vínculo.

Nessa esteira, Jhering teve como ponto de partida a seguinte questão: "Se um sujeito deu causa, por culpa sua, à nulidade de um contrato, deve ou não ressarcir o dano que a outra parte sofreu por haver confiado na validade do mesmo?" (apud CAPELARI, 1999, p. 19).

Portanto, a construção jurídica da culpa in contrahendo surgiu porque quem sofria prejuízo por haver confiado na validade de um contrato que outrem, por sua causa, havia tornado inválido, não tinha meios jurídicos para resguardar o seu direito de ressarcimento, o que feria o "sentimento comum de justiça". Seria uma espécie de culpa anterior à formação do contrato, assim Jhering 
visou tutelar a confiança recíproca que deve presidir a conduta das partes durante todo o tráfico jurídico.

Nessa construção da responsabilidade contratual culpa in contrahendo, extrai-se que somente os contraentes podem incorrer nessa espécie de culpa, pois pressupõe-se a vinculação estrita entre as partes, que o fim colimado entre os sujeitos seja o de formação de um contrato. Após os estudos de Jhering, seguiram-se os de Faggela, que foi o segundo grande tratadista da responsabilidade pré-contratual, tendo o mérito de introduzir o tema no campo da doutrina latina.

Informa Maria C. Cachapuz (1999, p. 69) que a ideia lançada por Fagella foi aperfeiçoada por Saleilles, na França, com a inclusão do elemento da boa-fé como fonte de responsabilidade pré-contratual. Prescinde-se, pois, do elemento da culpa, em verdade, para a verificação do dever de reparar. O que se torna fundamental é avaliar o grau de confiança depositado pelas partes contratantes no período das tratativas negociais, a fim de se ver caracterizada a responsabilidade pré-contratual.

Todavia, após esses tratadistas, houve certo abandono do assunto, e apesar da doutrina de Jhering ser brilhante, faltava ainda resolver tópicos importantes, como o fundamento da obrigação de ressarcir, a extensão do período que alcança a responsabilidade pré-contratual, a extensão do ressarcimento e tantos outros assuntos atinentes à matéria ainda indefinidos.

Uma das críticas, a nosso ver, mais contundentes à teoria de Jhering diz respeito ao fundamento do ressarcimento estabelecer-se com base na culpa, o que poderia deixar a descoberto os casos em que não havia culpa.

Também houve os que questionaram o seguinte: ou a responsabilidade é contratual ou extracontratual, não concebendo que antes que o acordo tenha lugar, possa dar ensejo a qualquer responsabilidade. Essa ideia da culpa in contrahendo hoje é chamada de responsabilidade extracontratual, conforme os artigos 186 e 927, caput, do Código Civil de 2002.

Roberto H. Brebbia, (1957, p. 36-38) cumpre salientar, entende que se o contrato não chegou a concluir-se, contrato não houve, nem há, por via de consequência, responsabilidade contratual. Que o fundamento da obrigação de indenizar reside na culpa, e que essa culpa é da mesma natureza que os atos ilícitos. O artigo 1198 do Código Civil argentino contempla expressamente o princípio da boa-fé.

Entende-se que o fundamento da responsabilidade pré-contratual deve ser inferido, principalmente, consoante o direito positivo de cada país, e nos 
filiamos à corrente segundo a qual a responsabilidade, nesses casos, advém do comportamento das partes, de uma ofensa ao princípio geral de não lesar neminem laedere. Nesse passo, cumpre salientar que o comportamento das partes deve ser pautado pela observância ao princípio da boa-fé objetiva, como um dever lateral ou correlato de conduta, em face da obrigação principal. ${ }^{1}$ (NORONHA, 1994, p. 147).

Assim, consta do art. 1337 do Código Civil italiano, de 1942: "as partes, no decurso das negociações e na formação do contrato, devem comportar-se segundo a boa-fé”. (ITALIA, 2012). Logo, da violação desta obrigação e dos danos daí derivados para a contraparte resulta a chamada responsabilidade pré-contratual. Importa ressaltar que esse artigo consubstancia uma cláusula geral, possibilitando a configuração de uma gama ilimitada de hipóteses de configuração da responsabilidade pré-contratual.

A ruptura das negociações, para ensejar indenização, precisa ser injusta e arbitrária.

Como se mede o ressarcimento devido à parte lesada?

Para Roppo, (1988, p.96-109) a parte lesada tem direito à indenização que corresponda às vantagens que teria obtido somadas aos danos e despesas que teria evitado, se não tivesse iniciado as negociações, que depois foram injustificadamente interrompidas pela contraparte.

Não se pode esquecer que em face da constitucionalização do direito civil, em se tratando das relações negociais, há uma ênfase na boa-fé e na função social do contrato. Assim, mesmo não havendo previsão legal específica para essa espécie de responsabilidade, a doutrina e a jurisprudência pátrias, por meio de uma interpretação sistemática e principiológica, a admitem.

Por outro lado, o Código Civil Brasileiro, em seu art. 427, estabelece o princípio da vinculação ou da obrigatoriedade da proposta, que determina que a proposta de contratar, regra geral, obriga o proponente. Trata-se a aceitação, por sua vez, da aquiescência, por uma das partes, a uma proposta anteriormente formulada pela outra. Cumpre observar que o contrato só se forma com a junção destas últimas fases, com a reunião entre a proposta e a aceitação.

Segundo Pablo Stolze Gagliano e Rodolfo Pamplona Filho, (2009, p. 90) neste momento prévio "[...] as partes discutem, ponderam, refletem, fazem cálculos, estudos, redigem a minuta do contrato, enfim, contemporizam interesses

1 Recomendável para um maior aprofundamento do tema: a boa-fé contratual e seu alcance, função interpretativa da boa-fé, função integrativa da boa-fé e função de controle. 
antagônicos, para que possam chegar a uma proposta final e definitiva." Sílvio Venosa (2012, p. 474) entende que

[...] em qualquer situação em que se avalie a hipótese de uma responsabilidade anterior ao contrato, deve preponderar o exame da quebra de confiança. [...] o que responsabiliza é a recusa arbitrária de contratar. Não se trata exatamente de uma responsabilidade pré-contratual, porque contrato ainda inexiste, mas de um aspecto da responsabilidade aquiliana que tem a ver com o universo contratual. Há sempre a necessidade de analisar o caso concreto e a questão deve-se resolver em perdas e danos.

A maioria dos estudiosos concorda com Venosa na adoção da teoria da responsabilidade extracontratual. Tradicionalmente se defende que na responsabilidade civil pré-contratual, regra geral, há a exigência da culpa, em sua modalidade in contrahendo.

O parágrafo único do art. 927 do Código Civil Brasileiro afirma que apenas há a obrigação de reparar o dano, independente de culpa, nos casos previstos em lei, ou quando atividade normalmente desenvolvida pelo autor do dano implicar, por sua natureza, risco para os direitos de outrem. Há possibilidade de se dispensar a exigência da culpa, quando o dano advém da quebra da boafé objetiva? Acredita-se que esse aspecto necessita de aprofundamento doutrinário.

Há também a diferenciação legal entre responsabilidade civil précontratual e a responsabilidade que surge do descumprimento de uma modalidade contratual: o contrato preliminar, previsto nos artigos 462, 463 e 464 do Código Civil. Segundo Venosa:

[...] não se deve confundir as negociações preliminares com o contrato preliminar, como regra as negociações preliminares não geram direitos. Todavia, quando falamos em responsabilidade pré-contratual ela decorre justamente dos danos causados na fase de negociações, fora do contrato, indenizáveis sob a égide do art. 186. Na esfera dos negócios mais complexos, é comum que as partes teçam considerações prévias, ou firmem até mesmo um protocolo de intenções, mas nessas tratativas preliminares ainda não existem os elementos essenciais de um contrato [...] o pré-contrato tem força vinculante, maiormente sentida quando a promessa é irretratável, pode ser até mesmo exigida judicialmente a conclusão do contrato definitivo. (VENOSA, 2012, p. 418). 
A responsabilidade civil pré-contratual, por sua vez, surge quando há dano causado a uma das partes, em razão de um rompimento injustificado pela parte que criou no lesado a expectativa de contratação.

À jurisprudência cabe um papel fundamental na explicitação e no desenvolvimento dessa espécie de responsabilidade, o que vem ocorrendo. Citam-se, a título exemplificativo, decisões que privilegiam a confiança e a boafé, na linha de interpretação preconizada por Reale (1999).

RESPONSABILIDADE CIVIL. COMPRA E VENDA DE "PONTO COMERCIAL". INOBSERVÂNCIADO PRINCÍPIO DABOA-FÉNAFASE PRÉ-CONTRATUAL. DANOS MATERIAIS E MORAIS CONFIGURADOS. LUCROS CESSANTES NÃO CONFIGURADOS. I - Os contratantes devem agir com transparência, lealdade e probidade, inclusive na fase pré-contratual, respeitando a boa-fé objetiva que rege as relações contratuais. Hipótese na qual houve omissões a fatos essenciais à celebração do contrato, atitude que não se coaduna com a conduta esperada nas relações jurídicas, dando causa ao rompimento do pacto e ao dever de indenizar, forte no art. 187 e 927 , ambos do Código Civil. II - Omissão quanto ao real faturamento do negócio, bem como sobre a possibilidade de o imóvel ser posto a venda justificam a indenização da autora ao dano moral experimentado. As adversidades sofridas pela autora, a aflição e o desequilíbrio em seu bem-estar, fugiram à normalidade e se constituíram em agressão à sua dignidade. III - Manutenção do montante indenizatório considerando a conduta da parte ré, o aborrecimento e o transtorno sofridos pela demandante, além do caráter punitivo-compensatório da reparação. IV - Considerando que a autora investiu em reformas no imóvel para continuar explorando o ponto comercial e que isto não foi possível, em razão da venda do imóvel, patente é o dever de indenizar o dano material. V - [...] a aquisição de um empreendimento, de uma empresa ou de um ponto comercial não gera automaticamente certeza de lucro ou ganhos. Assim, o montante que a autora alega ter deixado de perceber trata-se de uma previsão de faturamento que lhe foi passada, mas não de um ganho certo que percebia e deixou de perceber por um ato praticado pelas rés. APELAÇÃO DESPROVIDA. (Apelação Cível N 70048335574, Décima Câmara Cível, Tribunal de Justiça do RS, Relator: Túlio de Oliveira Martins, Julgado em 19/ 07/2012).

RESPONSABILIDADE CIVIL. OBRA LITERÁRIA. ROMPIMENTO DO CONTRATO AINDA NA FASE DS TRATATIVAS. BOA-FÉ OBJETIVA. DANO MORAL CONFIGURADO. DANO MATERIAL INEXISTENTE. I Os contratantes devem agir com transparência, lealdade e probidade, inclusive 
na fase pré-contratual respeitando a boa-fé objetiva que rege as relações contratuais. Hipótese na qual a inclusão de pessoa como coautora de obra literária, de forma arbitrária, não transparente e quando já avançadas as tratativas para a confecção do livro, não se coaduna com a conduta esperada nas relações jurídicas, dando causa ao rompimento do pacto e ao dever de indenizar, forte no art. 187 e 927, ambos do Código Civil. II - O rompimento da negociação, após três meses de tratativas, inclusive com captação de recursos junto aos patrocinadores, realização de todas as etapas preliminares, tais como aprovação do protótipo, preparo da divulgação, etc. acarreta dano moral indenizável. As adversidades sofridas pela autora, a aflição e o desequilíbrio em seu bem-estar, fugiram à normalidade e se constituíram em agressão à sua dignidade. III - Manutenção do montante indenizatório considerando o equívoco dos réus, o aborrecimento e o transtorno sofridos pela demandante, além do caráter punitivo-compensatório da reparação. IV O dano material não se presume. In casu, pelo que restou acordado entre as partes, o recebimento dos valores estava condicionado à venda dos livros. Assim, se trata de um lucro hipotético, imaginário, o qual não se coaduna com o lucro cessante. APELAÇÕES DESPROVIDAS. (Apelação Cível No 70045843901, Décima Câmara Cível, Tribunal de Justiça do RS, Relator: Túlio de Oliveira Martins, Julgado em 16/02/2012). (RIO GRANDE DO SUL, 2012).

Em ambos os casos colacionados acima, verifica-se a observação com rigor de violação do princípio da boa-fé contratual, mesmo em sede de précontrato, pois trata de elemento objetivo das relações contratuais brasileiras, ratificado pela legislação pátria. Afirmam que as ações, mesmo nas tratativas anteriores à assitura derradeira de um contrato, deve observar os deveres de transparência, lealdade e probidade entre as partes. Portanto, a possibilidade de indenização aos prejudicados pelos danos causados de forma patrimonial e extra-patrimonial restou configurada no entendimento dos julgadores.

\section{O CONCEITO EAABRANGÊNCIA DA RESPONSABILIDADE PRÉ-CONTRATUAL ÀS RELAÇÕES EMPREGATÍCIAS}

Em princípio, cumpre que se façam algumas considerações acerca do termo "responsabilidade pré-contratual". A expressão "responsabilidade prénegocial" mostra-se mais correta, pois sabe-se que o problema transcende o puro domínio dos contratos, abrangendo os negócios jurídicos unilaterais e, inclusive, os quase negócios jurídicos ou atos quase negociais (interpelação do devedor, notificação de cessão, entre outros). 
No entanto, a expressão "responsabilidade pré-contratual" congrega a preferência dos autores, o que se justifica pela circunstância de os contratos serem o domínio de eleição do instituto. Importa frisar que o negócio jurídico é um gênero do qual o contrato é apenas uma espécie. Fernando Noronha (2007, p. 64) assim conceitua responsabilidade pré-contratual:

Consiste na obrigação de reparar os danos derivados da conduta de uma das partes, nas negociações preliminares de um contrato, quando se crie na contraparte, com uma conduta desleal, a convicção de que o negócio se realizaria e seria válido, assim levando esta a realizar despesa para poder cumprir a sua parte no negócio, a abster-se de contratar com outras pessoas, ou mesmo a deixar de realizar outros negócios.

Adota-se esse conceito, por ser amplo, abordando, inclusive, os casos de responsabilidade pré-contratual objetiva, quando há responsabilidade decorrente de fato de outrem, como a do preposto e do menor. Inclui-se na definição, para os fins desse estudo, a responsabilidade pré-contratual decorrente das relações empregatícias, no que diz respeito ao procedimento de seleção dos candidatos às vagas oferecidas pelas empresas.

De outro prisma, em caráter preliminar, cuida-se de não se confundir responsabilidade pré-contratual com o denominado pré-contrato. A sua violação gera, pois, a responsabilidade própria do não cumprimento de um contrato, pois o pré-contrato, na verdade, tem natureza contratual. Ele é muito utilizado em nosso país, e como exemplo podemos citar a promessa de compra e venda.

Mário Júlio de Almeida Costa $^{2}$ (1984) coloca três situações aptas a ensejar a indenização, no concernente à responsabilidade pré-negocial, quais sejam:

a) ausência ou não conclusão de um contrato cujas negociações se iniciaram;

b) celebração de um contrato ferido de invalidade ou ineficácia;

c) conclusão de um contrato válido e eficaz, em que surgiram das respectivas negociações danos a indenizar.

Porém, a doutrina não é unânime quanto à qualificação dessas situações como de responsabilidade pré-contratual. Fernando Noronha (2007, p. 66) entende que tanto a interrupção injustificada das negociações preliminares como

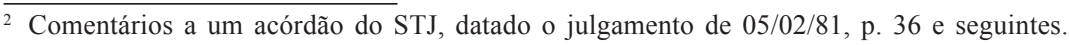


a violação dos demais deveres de conduta que recaem sobre as partes durante tais negociações, caracterizam sempre infração ao princípio da boa-fé.

Entende-se que há requisitos necessários e suficientes a ensejar a incidência da responsabilidade pré-contratual, quais sejam: confiança na realização do futuro negócio; poder-se atribuir uma justificação para a confiança; essa confiança ter sido gerada pela contraparte ou por quem o represente; quebra imotivada dessa confiança a partir da violação de qualquer dever de conduta; a ocorrência de um dano e a relação de causalidade.

No que tange às relações empregatícias, há situações que realmente podem configurar constrangimentos envolvendo candidatos e empregadores, tendo em vista a espécie impar e peculiar que envolve o contrato de emprego, por sua origem desequilibrado ante a hipossuficiência dos empregados e candidatos à vagas de emprego perante o poder econômico do empregador.

Nas tratativas prévias à contratação dos funcionários, é perfeitamente possível que as empresas recebam informações sobre o histórico profissional dos candidatos, suas experiências e qualificações. (PAMPLONA FILHO, 2013).

Dessa forma, parafraseando entendimento de José Affonso Dallegrave Neto (2005), verifica-se que um possível dano não decorre do contrato de emprego, e sim de um dever de conduta na fase pré-contratual, impondo-se a observância do princípio da boa-fé positivado no artigo 422 do Código Civil brasileiro.

Ocorrendo o dano pela não contratação, ou seja, não celebração do contrato de emprego, violou-se o vínculo onde se estabeleceu efeito vinculante entre candidato e empresa. Assim, verifica-se que a responsabilidade civil, pela conduta ocorrida na fase pré-contratual, decorre da quebra do dever da boa-fé, enquadrando-se de forma emergente na responsabilidade contratual. $\mathrm{O}$ fato pode gerar danos materiais e até mesmo morais ao atingido, no que diz respeito às despesas e prejuízos relativos à não realização do negócio jurídico. Diz José Affonso Dallegrave Neto (2007, p. 106):

O interesse contratual positivo abrangem-se todas as conseqüências da ineficácia de um contrato supostamente válido, havendo interesse na própria execução do contrato. Já o interesse contratual negativo atinge apenas o prejuízo traduzido no que a parte perdeu ou deixou de ganhar em fase da negociação encetada e posteriormente frustrada pela parte adversa; geralmente são despesas que sofreu para se credenciar negociação ou em razão do tempo que gastou (dano emergente), abrangendo também as oportunidades imediatas que deixaram de se concretizar (lucro cessante) em face da frustrada quebra ou vício contratual da parte contrária. 
No que diz respeito aos danos extra-patrimoniais, há prática nas seleções de empregados, o uso de exames físicos e testes psicotécnicos totalmente subjetivos com intuito de investigar a personalidade dos candidatos não só para o desenvolvimento da atividade profissional, mas se costumes pessoais poderão ou não interferir. Dependendo da forma como estão sendo aplicados os testes, podem causar danos morais passíveis de indenização por violação à intimidade e honra das pessoas configurando-se prática discriminatória. (BARROS, 1997).

No entanto, é preciso ressaltar que não há que se falar em indenização na fase pré-contratual sem que ocorra a demonstração dos prejuízos causados. Não trata-se de dano moral objetivo (in ré ipsa), sendo ônus do candidato a demonstração do fato e suas consequências negativas.

\section{ASPECTOS DESTACADOS DA BOA-FÉ NO DIREITO BRASILEIRO E NO DIREITO COMPARADO}

Mister se faz ressaltar, em primeiro lugar, que a boa-fé se apresenta sob dois enfoques, o objetivo e o subjetivo. Cogita-se, nesse estudo, a boa-fé objetiva, que conduz os contratantes à honestidade, lealdade e correição. ${ }^{3}$ A boa-fé objetiva é princípio consagrado expressamente pelo Código Civil Brasileiro, que, em seu art. 422, exige seja a mesma observada pelos contratantes, tanto na conclusão do contrato, como em sua execução.

Nesse passo, cumpre salientar que o Código Civil alemão, dentre os examinados da doutrina estrangeira, é o que melhor desenvolve a doutrina da responsabilidade pré-contratual. Assim, no sistema tedesco a responsabilidade pré-contratual decorre da força do compromisso do contato social, de uma responsabilidade pela confiança aludida.

De outra banda, cumpre ressaltar que também no Código de Defesa do Consumidor há o princípio da boa-fé objetiva, ou a chamada cláusula geral da boa-fé, ${ }^{4}$ refletida em inúmeros artigos. Pode-se citar, por exemplo, o artigo 51,

\footnotetext{
3 Note-se que há diferença entre a boa-fé subjetiva e a objetiva, uma vez que a boa-fé subjetiva é o oposto da má-fé. Consubstancia-se "na intenção de lesar a outrem, ou seja, um 'estado de consciência', ou convencimento individual de obrar (a parte) em conformidade ao direito, (sendo) aplicável em regra, ao campo dos direitos reais, principalmente em matéria possessória. Já a boa-fé objetiva traduz um modelo de conduta social, arquétipo ou standard jurídico, segundo o qual cada pessoa deve ajustar a própria conduta a esse arquétipo, obrando com honestidade, lealdade e probidade." Ver: Martins-Costa (2000. p. 410).

${ }^{4}$ Para um perfeito entendimento sobre cláusula geral, recomenda-se a leitura do artigo $O$ direito privado como um "sistema em construção", da professora Judith Martins-Costa, disponível na internet, no site do curso de Mestrado em Direito da Universidade Federal do Rio Grande do Sul. Ver em: Martins-Costa (1998, p. 129-154).
} 
IV que tipifica várias hipóteses legais de deveres que, se não tivessem sido previstos na lei, incluir-se-iam no âmbito da concreção da boa-fé objetiva.

O princípio da boa-fé na formação contratual pode não só se consubstanciar numa regra genérica, mas também se desdobrar em regras específicas, tais como o dever de informar a contraparte, dever de manter sigilosas as informações, dever de cooperação.

Pode, no observar do professor Azevedo, (1996, p. 27) ocorrer a caracterização da responsabilidade pré-contratual também por parte do consumidor:

[...] na hipótese do pedido de reserva do produto, antes de qualquer contrato, [...] o consumidor que, despertada a confiança do fornecedor, depois a frustra, não indo buscar o produto, pode causar prejuízo; o fornecedor, por sua vez, se promete a reserva e, depois, não a faz, também pode causar dano ao consumidor.

Por outro lado, no Código de Defesa do Consumidor, há várias regras impondo o dever de informar. Para exemplificarmos, podemos citar o art. $6^{\circ}$ do CDC, que entre os direitos básicos do consumidor, inclui "o direito à informação". Assim, entende Mário Júlio de Almeida Costa (1992) que a responsabilidade pré-contratual, em sua plena dimensão, deriva do princípio fundamental subjacente ao ordenamento jurídico: o da boa-fé.

Há, pois, infrações aos deveres de conduta, de portar-se conforme a boa-fé. A boa-fé deve ser o norte dos que estão em processo de tratativas, ela deve limitar, deve ser a fronteira do princípio da liberdade negocial. A ofensa à boa-fé objetiva constitui o suporte fático suficiente a caracterizar a responsabilidade pré-negocial. Interessante opinião acerca da responsabilidade pré-contratual é a esposada por Ricardo Lorenzetti (1998, p. 536):

Há antes que se aperfeiçoe o consentimento, no período das negociações, há obrigações de informação, de lealdade, de boa-fé, cuja origem legal é evidente, e cujo descumprimento dá origem à responsabilidade précontratual. [...] A negociação foi, tradicionalmente, um espaço de irrelevância normativa, já que é lícito comerciar, e em consequência, não contratar. Mas enquanto esse contato social produz uma expectativa, cuja frustração resulta danosa na esfera de interesse da outra parte, há responsabilidade. [...] A responsabilidade pré-contratual distribui os riscos econômicos da negociação de uma maneira distinta da que faz a autonomia privada. 
Ele quer dizer que a malandragem, a astúcia negocial sofre um recorte, já que está limitada pela boa-fé. Ao passo que a vetusta autonomia da vontade não tinha esse limite.

Após ter criado uma justificativa, frente à conduta seguramente indicativa que determinado comportamento previsível e futuro ocorreria, uma parte frustra a expectativa e fere os princípios de lealdade e confiança, havendo assim a ruptura da boa-fé em razão da surpresa e do prejuízo causado à contraparte.

Nesse sentido, para um entendimento mais amplo da problemática da responsabilidade pré-contratual, à guisa de exemplificação, cita Maria Cristina Cereser Pezzella (1997, p. 54) os seguintes casos: Em uma prestação positiva, como a entrega de um cavalo para o dia primeiro do próximo mês, não se deve apenas atentar para a execução da atividade que o credor procura imediatamente, vale dizer, a entrega da coisa devida, pois existe mais: o devedor deve também omitir tudo aquilo que puder frustrar ou pôr em perigo a satisfação da obrigação (por exemplo, fazer o cavalo trabalhar excessivamente). Deve, igualmente, adotar medidas positivas que resultem na conservação da possibilidade da prestação, como alimentar e passear com o cavalo. O mesmo se dá quando estamos diante de uma obrigação negativa. É o que ocorre quando, por exemplo, a parte atribui a seu vizinho um direito pessoal que permite a ele a utilização do caminho de sua propriedade para atingir a via pública, estando por isso obrigada, conforme a boa-fé objetiva, a adotar medidas de caráter positivo que permitem o exercício do direito de passagem, sobretudo, deixando a porteira aberta durante o tempo necessário.

Na Apelação Cível n n 591028295, caso julgado pela $5^{\circ}$ Câmara Cível do tribunal de Justiça do Rio Grande do Sul, reconheceu-se a existência da responsabilidade pré-contratual por parte da Companhia Cica que, costumeiramente, adquiria dos autores, agricultores gaúchos, toda a sua produção de tomates. Porém, diferentemente da conduta habitual, na safra de 1987/88, apesar de ter fornecido as sementes para o plantio, recusou-se a adquirir a produção, o que se deu de forma imotivada.

Esse é um nítido caso jurisprudencial de aplicação da boa-fé objetiva.

Convém notar, outrossim, que, quando visualizamos a obrigação como um processo dinâmico, constata-se que os deveres secundários da relação contratual não se constituem numerus clausus; eles podem, inclusive, surgir antes da contratação, na fase do "contato social". Logo, os deveres secundários ou anexos podem surgir antes da efetiva conclusão do contrato e 
supõem, em regra, uma obrigação existente.

Com essa transformação, as normas do direito privado devem adequarse aos princípios jurídicos norteadores da ordem macrossocial, como o respeito à boa-fé. Entende-se, nesse passo, que a indenização, no âmbito da responsabilidade pré-contratual, uma vez consubstanciados os pressupostos a ensejar a indenização, deve ser integral, compreendendo não apenas o dano efetivo, como também o que a pessoa deixou de ganhar em razão da confiança depositada para a execução do negócio futuro e, se for o caso, também a reparação moral, consoante o artigo $5^{\circ}, \mathrm{X}$ da Constituição.

O âmbito da responsabilidade pré-contratual vai até a celebração do contrato, quer o definitivo, quer um contrato preliminar, como é o compromisso de compra e venda.

\section{CONSIDERAÇÕES FINAIS}

Em princípio, cumpre salientar que a importância da responsabilidade pré-contratual cresceu muito nos dias hodiernos e que o fundamento da responsabilidade civil pré-contratual é o descumprimento da boa-fé objetiva e, por conseguinte, dos deveres contratuais acessórios que dela decorrem, especialmente nas relações empregatícias.

Por outro lado, hoje predominam os contratos continuados: contratos bancários, de cartões de crédito, de saúde, de telefone e luz elétrica. Isso contribui para que a responsabilidade pré-contratual adquira uma nova dimensão e importância.

O princípio da boa-fé objetiva deve ser sempre observado, na medida em que vai ao encontro de necessidades éticas essenciais e os magistrados devem estar atentos a essa peculiaridade hodierna.

Ademais, em virtude da aplicação do princípio da boa-fé objetiva no direito obrigacional, aqui abrangendo as relações de emprego, passou-se a ter em alta consideração a relação obrigacional como uma ordem de cooperação entre as partes, para satisfazer os interesses do credor com a necessária preservação dos interesses do devedor. Assim, a imagem da obrigação como dever de prestar, separando credor e devedor em dois pólos antagônicos, já se apresenta ultrapassada e insuficiente.

Hoje, quando se fala no "controle do contrato", alude-se ao controle da licitude e, com efeito, foi precisamente esse tipo de controle que adquiriu maior relevo no campo contratual, a ponto de a recente história do direito 
privado poder ser descrita como a história da progressiva e sempre mais penetrante restrição por obra do ordenamento na esfera de autonomia contratual privada.

Talvez, hoje, haja uma revalorização da responsabilidade pré-contratual, também em virtude da mudança no que condiciona o próprio nascimento da relação contratual, não mais fincado nas declarações de vontade válidas, mas sim com base no "contato social" que se estabelece entre as partes dessa mesma relação. Leva-se em conta o complexo de circunstâncias e comportamento que as partes realizam, o que enseja, de fato, operações econômicas e transferências de riqueza entre os sujeitos.

$\mathrm{O}$ "contato social” toma o lugar do contrato propriamente dito. Isso dá margem a uma revalorização, uma nova dimensão a essa peculiar espécie de responsabilidade, de modo que todos os prismas pertinentes à responsabilidade pré-contratual devem ser vistos sob a ótica da boa-fé objetiva, principalmente no contrato de emprego, por envolver hipossuficiência no tocante ao trabalhador ou candidato à vaga de trabalho ofertada.

Dessa forma, entende-se que o fundamento da responsabilidade précontratual não é contratual, porque ainda não há contrato, nem extracontratual, eis que, estando os contraentes em negociações, eles têm deveres específicos decorrentes do "contato social", e sob a ótica da obrigação jurídica ser um processo, ou melhor, uma sucessão de tempos que são subordinados à boa-fé objetiva, nada mais natural e lógico que a boa-fé, em seu sentido objetivo, deva ser compreendida como o fundamento de tal responsabilidade.

Assim, à medida que evoluem os estudos no sentido de que os deveres de conduta devem pautar-se segundo a boa-fé, e que, inclusive, podem criar vínculos independentes entre as partes, e que ainda na fase do contato social pode haver a ocorrência de fatos capazes de gerar responsabilidade, aproxima-se, cada vez mais, a ideia de contrato associada a de responsabilidade civil.

\section{REFERÊNCIAS}

AZEVEDO, Antônio Junqueira. Responsabilidade pré-contratual no Código de Defesa do Consumidor: estudo comparativo com a responsabilidade précontratual no direito comum. Revista de Direito do Consumidor, São Paulo, n. 18, p. 23-31, maio/ago. 1996. 
BARROS, Alice Monteiro. Proteção à intimidade do empregado. São Paulo: LTr, 1997.

BREBBIA, Roberto. Responsabilidad precontractual: evolución de la doctrina, ensayo de un sistema de responsabilidad precontractual en el derecho argentino. Rosario: V. P. Zavalia, 1957.

CACHAPUZ, Maria Cláudia. Algumas notas sobre a responsabilidade précontratual. Revista da Ajuris, Porto Alegre, ano 26, n. 76, p. 65-86, dez. 1999.

CAPPELARI, Récio Eduardo. Responsabilidade pré-contratual: aplicabilidade ao direito brasileiro. Porto Alegre: Livraria do Advogado, 1995.

COSTA, Mário Júlio de Almeida. Responsabilidade civil pela ruptura das negociações preparatórias de um contrato. Coimbra: Coimbra Ed., 1984.

COSTA, Mário Júlio de Almeida. O direito das obrigações. Porto Alegre: Ajuris, [1992]. Conferência ministrada em 13 nov. 1992. 1 cassete sonoro.

DALLEGRAVE NETO, José Affonso. Responsabilidade civil no direito do trabalho. São Paulo: Ltr, 2005.

. Responsabilidade civil no direito do trabalho. São Paulo: LTr, 2007.

GAGLIANO, Pablo Stolze; PAMPLONA FILHO, Rodolfo. Novo curso de direito civil: contratos: teoria geral. 5. ed. São Paulo: Saraiva, 2009. v. 4, t. 1 .

ITALIA. Il Codice Civile Italiano. In: THE CARDOZO Electronic Law Bulletin. Disponível em: < http://www.jus.unitn.it/cardozo/obiter_dictum/ codciv/Lib4.htm>. Acesso em: 1 out. 2012. Tradução livre. 
LORENZETTI, Ricardo. Fundamentos do direito privado. São Paulo: Revista dos Tribunais, 1998.

MARTINS-COSTA, Judith. A boa-fé no direito privado: sistema e tópica. São Paulo: Revista dos Tribunais, 2000.

. O direito privado como um "sistema em construção": as cláusulas gerais no projeto do código civil brasileiro. Revista da Faculdade de Direito da UFRGS, Porto Alegre, n. 15, p. 129-154, 1998. Disponível em: $<$ http://www.ufrgs.br/ppgd/doutrina/martins1.htm>. Acesso em: 1 out. 2012.

NORONHA, Fernando. O direito dos contratos e seus princípios fundamentais: autonomia privada, boa-fé e justiça contratual. São Paulo: Saraiva, 1994.

. Direito das obrigações: fundamentos do direito das obrigações e introdução à responsabilidade civil. 2. ed. São Paulo: Saraiva, 2007. v. 1.

PAMPLONA FILHO, Rodolfo. Responsabilidade civil nas relações de trabalho e o novo código civil brasileiro. Disponível em:

<www.jus.com.br.>. Acesso em: 1 jul. 2013.

PEZZELLA, Maria Cristina. O princípio da boa-fé objetiva no direito privado alemão e brasileiro. Estudos Jurídicos, São Leopoldo, v. 30, n. 78, p. 47-76, 1997.

POPP, Carlyle. Responsabilidade civil pré-negocial: o rompimento das tratativas. Curitiba: Juruá, 2001.

REALE, Miguel. O projeto do novo código civil: situação após a aprovação pelo Senado Federal. 2. ed. São Paulo: Saraiva, 1999.

RIO GRANDE DO SUL. Tribunal de Justiça do Estado. Jurisprudência. Disponível em: $<$ http://www.tjrs.jus.br/busca/?tb=jurisnova $>$. Acesso em: 31 out. 2012. 
ROPPO, Enzo. O contrato. Coimbra: Almedina, 1988.

VENOSA, Sílvio de Salvo. Direito civil: teoria geral das obrigações e teoria geral dos contratos. 12. ed. São Paulo: Atlas, 2012.

Submetido em: 30/08/2013

Aprovado em: 27/12/2013

Como citar: RODRIGUES, Nina Trícia Disconzi; FERNANDES, Juliano Gianechini. A responsabilidade pré-contratual no Direito do Trabalho brasileiro. Scientia Iuris, Londrina, v.19, n.1, p.63-82, jun.2015. 